\title{
The Influence of Social Ties, Audit Tenure and Audit Fee towards Audit Quality
}

\author{
Teguh Ariyanto S.E , Dr. Zaenal Fanani SE., MSA.Ak \\ Faculty of Business and Economics \\ Airlangga University, Surabaya, \\ Indonesia
}

\begin{abstract}
This research is a quantitative study which aims to obtain empirical evidence regarding the influence of the external auditor's social ties with the CEO / CFO, the external auditor's social ties with the audit committee, audit tenure, and audit fees on audit quality. The sample of this research is 166 manufacturing companies which are listed on the Indonesia Stock Exchange (IDX) in the period 2017 to 2018. The data collection uses the purposive sampling. The data analysis technique used multiple regression statistical tests and $T$ statistical tests.

The results of this study indicate that the influence of the auditor's external social ties with the CEO / CFO on audit quality shows no significant effect (0.594> 0.1). The second hypothesis is that the effect of the auditor's external social ties with the audit committee shows no significant effect (0.946>0.1). The third hypothesis, the effect of audit tenure on audit quality, shows no significant effect $(0.217>0.1)$. The fourth hypothesis, the effect of audit fees on audit quality, shows that there is no significant effect $(0.331>0.1)$. It can be that the external auditors have worked professionally and independently which, despite the existence of social and economic ties, it does not affect the assessment of an external auditor.
\end{abstract}

Keywords: Social Ties, Audit Tenure, Audit Fees, Audit Quality.

\section{INTRODUCTION}

Financial reports are a means of communication regarding the financial condition of a company which will be used by several parties in making decisions (Harahap, Majidah, \& Triyanto, 2017) (Singgih \& Bawono, 2010). To convince users of financial statements, an audit of these financial statements is required. Where auditing is a process of inspection activities carried out by independent parties systematically and critically on the reasonableness of the financial statements (Arens, Elder, \& Beasley, 2008; Wiryanto, 2000). Therefore, an auditor or a public accounting firm is required to maintain the quality of the audit it does.

The social ties that occur between the external auditors and the company's CEO / CFO will affect the quality of the audit. According to research conducted by Kwak and Yu (2015), it shows that companies whose CEO / CFO have social ties with external auditors have lower audit quality. In this case, the social ties that occur between the external auditors and the CEO / CFO can lead to potential intervention by the two company executives in the audit process carried out by an external auditor. However, in this case, based on research by Kwon and Yi (2017), it shows different results, namely that there is a social ties that occurs between the CEO / CFO of the company and the external auditor which has high audit quality.

The audit committee is a committee owned by a company whose task is to supervise the accounting and financial reporting process of the company (Levitt \& Securities, 2000). According to research conducted by Carcello and Neal (2003), it shows that an audit committee that is truly independent will reduce the dismissal of audit agreements with external auditors who take unpopular policies. This is supported by research conducted by He, Pittman, Rui, and Wu (2017) which states that the social ties that occur between the audit committee and external auditors will affect audit quality, where on the one hand, social ties can hinder the involvement of external auditors in conduct thorough supervision and on the other hand the existence of social ties can facilitate the transfer of information to external auditors. 
Audit tenure will affect to audit quality which is shown based on research by González-Díaz, García-Fernández, and López-Díaz (2014) which states that audit quality will decrease with increasing audit tenure. However, according to research conducted by Knechel and Vanstraelen (2007), it shows a different matter where a long-term audit engagement will not damage the quality of the audit performed by an external auditor.

Audit fees have an effect on audit quality which is shown by the research of Hoitash, Markelevich, and Barragato (2007) which states that the amount of audit fees received by an external auditor will improve audit quality. This is reinforced by research conducted by Dao, Raghunandan, and Rama (2011) which states that high audit fees will make an external auditor more careful in carrying out his duties which will affect audit quality. However, this is different from the results of research conducted by Yuniarti (2011) which show that audit fees have no effect on audit quality.

In this case, the issue of audit quality has become a public spotlight in the last few decades in which public accounting firms have been involved. The scandal that occurred at Enron Corporation was one of the causes of the decline in public confidence in audit quality. In the Indonesian state itself, the case that Garuda Indonesia itself is quite in the public spotlight. In this case, the state-owned company financial statements found irregularities, namely the Garuda Indonesia Group booked a net profit of USD809.85 thousand or the equivalent of IDR 11.33 billion (assuming an exchange rate of IDR 14,000 per US dollar). This figure jumped sharply compared to 2017 which suffered a loss of USD216.5 million. The financial report caused a polemic because the two commissioners did not comply with the existing standards. In the case of PT. Garuda Indonesia Tbk itself, the external auditor, was considered negligent in auditing the 2018 financial statements.

After the case scandal that occurred at Enron Corporation, a rule or regulation called the Sarbanes oxley Act (SOX) has emerged to discipline the existing public accounting firm. SOX itself regulates the relationship between public accounting firms and public accountants and their clients. The emergence of these rules or regulations indirectly has an impact on the Indonesian state which makes the Indonesian state make a similar rule, namely the Minister of Finance Regulation No. 17 / PMK / 01/2008 which in 2015 was replaced by government regulation No. 20 of 2015 and in 2017 strengthened by the existence of regulations from the financial services authority number 13 / POJK.03 / 2017. The existence of these rules is expected to improve the quality of existing audits.

This study develops research from Qi, Yang, and Tian (2017) which provides empirical evidence that CEOs / CFOs who have social ties with external auditors will have an effect on audit quality. This study focuses not only on social ties but also on the economic ties that occur between external auditors and clients which affect audit quality. Garcia-Blandon and Argiles (2015) who provide empirical evidence that a long engagement or long audit tenure will affect audit quality. The economic ties that occur between external auditors and clients in this case are reflected in the audit fee, which according to research conducted by Hoitashdkk (2007) provides empirical evidence regarding audit fees which have a positive effect on audit quality.

Based on the above background, the questions of this research are (1) Does the social ties that occurs between the external auditor and the CEO / CFO affect the quality of the audit? (2) Does the social ties that occurs between the external auditor and the audit committee affect the quality of the audit? (3) Does audit tenure affect audit quality? (4) Does the audit fee affect the quality of the audit?

This research is expected to provide theoretical and practical contributions. The theoretical contribution expected in this study is to add insight into auditing issues and is expected to provide empirical evidence regarding the effect of social ties, audit tenure and audit fees on audit quality. A practical contribution in this case is expected to help investors in assessing an audit report which is carried out by an auditor, especially auditors who have the same educational background.

\section{LITERATURE REVIEW AND HYPOTHESIS DEVELOPMENT}

\subsection{The influence of social ties auditor eksternal with CEO/CFO On audit Quality}

CEO / CFO is also believed to have strengths and incentives which can affect financial reports (Bertrand \& Schoar, 2003; Habib \& Hossain, 2013). The CEO / CFO can also set strategies in the selection of accounting policies in which the choice of accounting policies can benefit him. Meanwhile, the auditor in this case has the duty to supervise and assess whether the report prepared by the management is in a reasonable condition. According to research by Qidkk (2017), which states that companies that have a CEO / CFO with social ties will have a positive effect on abnormal accruals and with small earnings reporting and are more likely to get better opinions than companies without social ties. This is supported by research conducted by Guan, $\mathrm{Su}$, Wu, 
and Yang (2016) which state that an auditor who has social ties with company executives will tend to give favorable opinions to the company executives. Based on the explanation above, the hypothesis is formulated as follows:

H1: The social ties that occur between the company's CEO / CFO and external auditors will affect audit quality.

\subsection{The influence of social ties that occur between the external auditors and the audit committee on audit quality}

The audit committee plays an important role in monitoring the integrity of company reports (Levitt \& Securities, 2000). In addition, the audit committee is also responsible for the appointment of an external auditor. So the audit committee and the external auditor in this case both act in supervising the performance of the management where the social bond between the audit committee and the external auditor will add information to the auditor about the condition of the company which will later affect the quality of the audit. based on research Carcello and Neal (2003) found that independent audit committees tend to reduce the dismissal of audit agreements with external auditors who make unpopular policies. This is also reinforced by research by Hedkk (2017), which suggests that companies whose audit committees have social ties with external auditors have a smaller probability of MAO (modified audit opinion) audit opinions than companies without social ties. Based on the explanation above, the hypothesis is formulated as follows:

H2: The social ties that occurs between the external auditor and the audit committee will affect the quality of the audit.

\subsection{Effect of Audit Tenure on Audit Quality.}

Audit tenure is the length of an engagement that occurs between an auditor and a client which will later affect the level of independence of an auditor which of course will also affect the quality of the audit. according to research Ghosh and Moon (2005) states that companies that have high audit tenure will also affect earnings estimates. This shows that the existence of a long tenure audit has made management more courageous in estimating profits. According to Carey and Simnett (2006) auditors with high audit tenure tend to be lower in issuing going concern opinions to companies experiencing problems. Based on the explanation above, the following hypothesis is formulated:

H3: Tenure audit will affect audit quality

\subsection{The Effect of Audit Fees on Audit Quality}

Audit fee or audit fee is a cost which is incurred by the company for the audit services that the auditor has provided for the company. According to Hoitashdkk (2007) states that the size and estimated costs incurred by the company to pay the auditors in this case represent the risks and efforts spent by an auditor during the audit process. According to research by Daodkk (2011), a high audit fee will make an auditor more careful in carrying out his duties which will improve the quality of the audit performed by an auditor. Based on the explanation above, the following hypothesis is formulated:

H4: Audit fees have an effect on audit quality

Based on the above hypothesis, the framework for the above research is as follows:

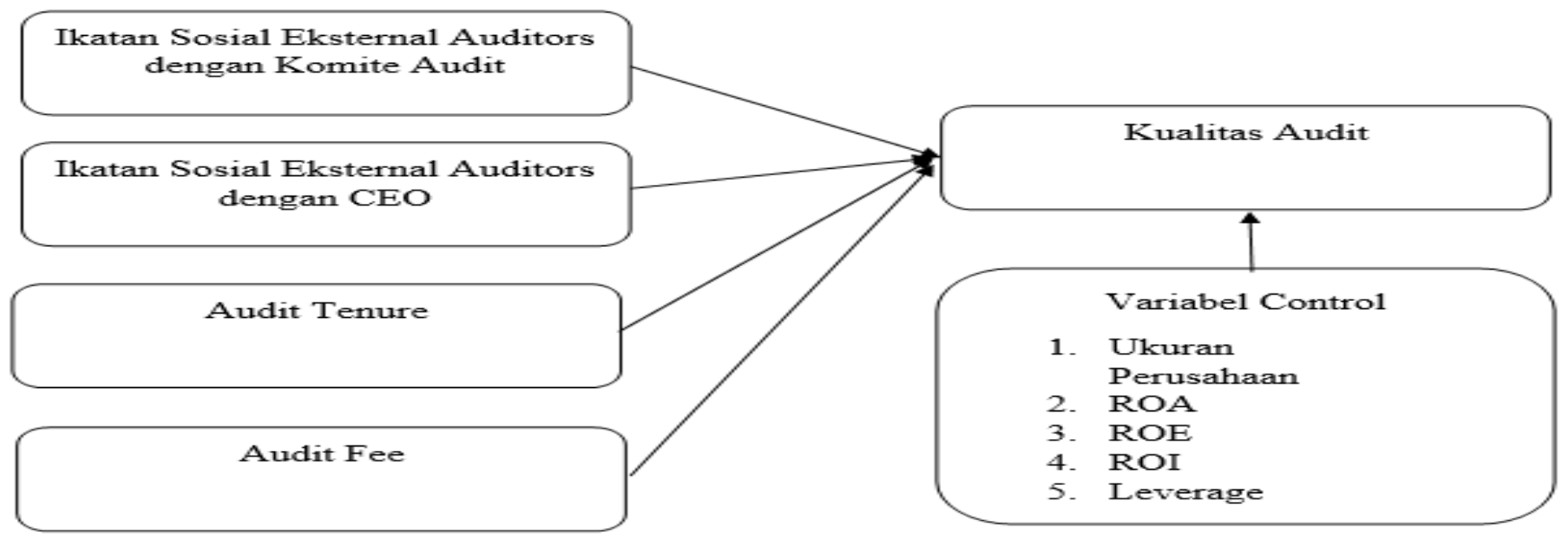

Figure1.1: Conceptual framework 


\section{RESEARCH METHODS}

\subsection{Research Model}

In this, the model used in this study is as follows:

$$
Y=B_{0}+B_{1} I S C+B_{2} I S K+B_{3} A T+B_{4} A F+B_{5} U P+B_{6} R O A+B_{7} R O E+B_{8} R O I+B_{9} \text { Leverage }+e
$$

Which is where the information is as follows:

$$
\begin{array}{ll}
\mathrm{Y} & =\text { Audit Quality } \\
\text { ISK } & =\text { Social Ties auditor eksternal With Audit Committe } \\
\text { ISC } & =\text { Social Ties Auditor Eskternal With CEO/CFO } \\
\mathrm{AT} & =\text { Audit Tenure } \\
\mathrm{AF} & =\text { Fee Audit } \\
\mathrm{UP} & =\text { Size Firm } \\
\mathrm{ROA} & =\text { Return On Asset } \\
\text { ROE } & =\text { Return On Equity } \\
\text { ROI } & =\text { Return On Investment } \\
\text { Leverage } & =\text { Leverage } \\
\mathrm{B}_{0} & =\text { constant, the value of Y if X1 = } 0 \text { and X2 = } 0 \\
\mathrm{~B}_{1} & =\text { variable regression coefficient X1 } \\
\mathrm{e} & =\text { error factor }
\end{array}
$$

\subsection{Operational definitions and variables}

\subsubsection{Audit Quality}

Based on GAO (1986) states that audit quality is a form of auditors' compliance with professional standards and contract provisions that are determined for certain audit services.

\subsubsection{Social Ties External Auditor to CEO/CFO}

Based on Kwon and Yi (2017) where the external social bond between the auditor and the CEO / CFO is a form of social network that occurs between the external auditor and the CEO / CFO which is characterized by the similarity of the same educational background.

\subsubsection{Social Ties External Auditor to Audit Committee}

Based on Hedkk (2017), there is a similarity in the same educational background that occurs between the external auditor and the audit committee.

\subsubsection{Audit Tenure}

Based on Garcia-Blandon and Argiles (2015), the audit tenure of a public accounting firm is the length of the year of the audit which was carried out consecutively by a public accounting firm.

\subsubsection{Audit Fee}

Based on Hoitashdkk (2007), audit fees are a measure of the costs incurred by a company to pay an external auditor or a public accounting firm to carry out the audit process.

\subsubsection{Size Firm}

Based on Suwito and Herawaty (2012) Company size is a scale which is used to describe the level of the company which is based on the size of the total assets owned. 


\subsubsection{Return On asset}

According to Fahmi (2012), Return On Asset is a probability ratio which describes the ability of a company to generate profits using its resources.

\subsubsection{Return On Equity}

According to Fahmi (2012), Return On Equity is a probability ratio which describes the ability of a company to generate profits

\subsubsection{Leverage}

Based on Guna and Herawaty (2010) Leverage is a ratio which compares the total liabilities to the company's total assets. This ratio shows the amount of assets which are financed by debt or liability.

\subsection{Population and Research Sample}

The population used in this study are companies listed on the Indonesian stock exchange. The samples used in this study are manufacturing companies listed on the Indonesian stock exchange from 2017 to 2018. The total number of manufacturing companies is 157 in the 2017 period and 168 in the 2018 period. There are 25 company data that cannot be accessed in the 2017 period. and in 2018 as many as 32. Unknown audit partner profile data in the 2017 period was 54 and in 2018 there were 58 so the final total sample used in this study was 166 companies.

\section{RESEARCH RESULT}

\subsection{Descriptive Statistics Test}

This section describes descriptive statistics generated from all the variables used in this study which consist of the dependent variable, the independent variable, and the control variable. Table 1 presents the results of the descriptive statistical test of the factors that influence audit quality.

Table 1

Descriptive Statistical Analysis

Descriptive Statistics

\begin{tabular}{|l|r|r|r|r|r|}
\hline & $\mathrm{N}$ & Minimum & Maximum & \multicolumn{1}{c|}{ Mean } & Std. Deviation \\
\hline KUALITAS AUDIT & 166 &,- 0027 &, 0221 &, 0007 &, 0027 \\
SOCIAL TIES CEO/CFO & 166 &, 0000 & 1,0000 &, 0904 &, 2876 \\
SOCIAL TIES KOMITE & 166 &, 0000 & 1,0000 &, 1145 &, 3193 \\
AUDIT & 166 &, 0000 & 1,0000 &, 6747 &, 4699 \\
AUDIT TENURE & 166 & 5,0348 & 11,9166 & 9,2533 & 1,0551 \\
AUDIT FEE & 166 & 11,1486 & 14,4722 & 12,3904 &, 6798 \\
UKURAN PERUSAHAAN & 166 &, 0012 &, 9675 &, 0953 &, 1292 \\
ROA & 166 &, 0004 & 2,6220 &, 1556 &, 2772 \\
ROE & 166 &, 0001 & 1,1278 &, 0830 &, 1266 \\
ROI & 166 &, 0622 &, 9895 &, 4096 &, 2027 \\
LEVERAGE & 166 & & & \\
Valid N (listwise) & & & &, \\
\hline
\end{tabular}

Sumber: Data diolah, 2020

\subsection{Multiple Regression Test Results}

This section explains the multiple regression analysis in this case it is used to test the effect of the independent variable on the dependent variable with more than one independent variable. The data obtained were then analyzed using the SPSS application where the results of the multiple linear regression test can be seen in Table 2 
Table 2

Multiple Regression Results

Coefficients $^{a}$

\begin{tabular}{|c|c|c|c|c|c|c|}
\hline \multirow[b]{2}{*}{ Mode } & & \multicolumn{2}{|c|}{ Unstandardized Coefficients } & \multirow{2}{*}{$\begin{array}{c}\begin{array}{c}\text { Standardized } \\
\text { Coefficients }\end{array} \\
\text { Beta }\end{array}$} & \multirow[b]{2}{*}{$t$} & \multirow[b]{2}{*}{ Sig. } \\
\hline & & $B$ & Std. Error & & & \\
\hline \multirow[t]{10}{*}{1} & (Constant) &, 002190 &, 003949 & &, 555 &, 580 \\
\hline & SOCIAL TIES CEO/CFO &,- 000416 &, 000779 &,- 044 &,- 534 &, 594 \\
\hline & $\begin{array}{l}\text { SOCIAL TIES KOMITE } \\
\text { AUDIT }\end{array}$ &, 000048 &, 000707 &, 006 &, 068 &, 946 \\
\hline & AUDIT TENURE &,- 000578 &, 000466 &,- 100 & $-1,241$ &, 217 \\
\hline & AUDIT FEE &, 000220 &, 000226 &, 085 & 975 &, 331 \\
\hline & UKURAN PERUSAHAAN &,- 000359 &, 000349 &,- 090 & $-1,028$ &, 305 \\
\hline & ROA &,- 001094 &, 001832 &,- 052 &,- 597 &, 551 \\
\hline & ROE &,- 000377 &, 001261 &,- 038 &,- 299 &, 765 \\
\hline & ROI &, 001896 &, 002877 &, 088 &, 659 &, 511 \\
\hline & LEVERAGE &, 003228 &, 001187 & 240 & 2,720 &, 007 \\
\hline
\end{tabular}

a. Dependent Variable: KUALITAS AUDIT

\subsection{Discussion of Research Results}

\subsubsection{The Effect of Social ties auditor eksternal with CEO/CFO on Audit Quality}

Based on the results of statistical tests, the significance level of $t$ for the social bond variable between the external auditor and the CEO / CFO on audit quality is 0.594 which is greater than the significance level $(\alpha) 0.01 ;(\alpha) 0.05$ and $(\alpha) 0.1$. This result shows that H1 is rejected. In this case the results of this study are different from the homophily theory and the results of Qidkk's (2017) research where previous research shows that there is an effect of social ties on audit quality. This is because the object of previous research was carried out in a country which has a strong kinship or guanxi culture while in this study it is in the country of Indonesia which has different culture and market characteristics.

\subsubsection{The Effect of Social ties auditor eksternal with Committee Audit on Audit Quality}

Based on the results of statistical testing, it shows that the significance level of $t$ for the social bond variable between the external auditor and the audit committee on the audit quality is 0.946 which is greater than the significance level $(\alpha) 0.01 ;(\alpha) 0.05$ and $(\alpha) 0.1$. These results indicate $\mathrm{H} 2$ is rejected. In this case the results of this study are different from the results of research by Hedkk (2017) where previous research shows that there is an effect of social ties on audit quality. This is because the object of previous research was carried out in a country which has a strong kinship culture, while in this study it was in the country of Indonesia which has different culture and market characteristics.

\subsubsection{The Effect of Audit Tenure on Audit Quality}

Based on the results of statistical testing where the significance value obtained from the t significance level for the audit tenure variable on audit quality is 0.217 which is greater than the significance level $(\alpha) 0.01 ;(\alpha) 0.05$ and $(\alpha) 0.1$. These results indicate that $\mathrm{H} 3$ is rejected. This research is in line with research conducted by Rinanda and Nurbaiti (2018) which states that the engagement period is not a benchmark for audit quality produced by external auditors but rather on the ability of an auditor and the auditor's compliance with existing audit standards.

\subsubsection{The Effect Audit Fee on Audit Quality}

Based on the results of statistical tests, it shows that the significance value obtained from the $t$ significance level for the audit fee on audit quality is 0.331 which is greater than the significance level $(\alpha) 0.01 ;(\alpha) 0.05$ and $(\alpha) 0.1$. These results indicate that $\mathrm{H} 4$ is rejected. In this case the results of this study are in line with the results of research conducted by Rinanda and Nurbaiti (2018) which state that the audit fee has no effect on the quality of the audit results where the quality of the audit results is determined by the ability of an auditor. In this case it shows that the size of the fee does not affect the skepticism of an auditor, where an auditor will maintain his skepticism and professionalism. 


\section{CONCLUSION, LIMITATIONS AND SUGGESTIONS}

Based on the results of statistical test analysis and the discussion described in the previous sub-chapter, it can be concluded that the social ties that occur between the external auditors and the CEO / CFO, the social ties that occur between the external auditors and the audit committee, audit tenure and audit fees have no effect on audit quality. which shows that the external auditors have worked in a professional, independent and objective manner in assessing the results of management reports. In this case this study has several limitations and suggestions for further research are as follows :

1. In this case the object of this research only focuses on manufacturing companies from 2017 to 2018 so that this research has limited generalization. Therefore, further research is expected to expand the object or research period so that the research results can be concluded in general.

2. The variables of this study are limited to social bonding factors which focus on the educational social ties that occur between the external auditors and the $\mathrm{CEO} / \mathrm{CFO}$ and the audit committee so that this research cannot be generalized to research on social ties that occur in external auditors and CEOs. / CFO as well as the audit committee. Further research is expected to expand the influence of social ties, where social ties are not only limited to educational social ties but also other social ties

\section{REFERENCES}

1. Arens, A. A., Elder, R. J., \& Beasley, M. S. (2008). Auditing dan jasa Assurance. Jakarta: Erlangga.

2. Bertrand, M., \& Schoar, A. (2003). Managing with style: The effect of managers on firm policies. The Quarterly journal of economics, 118(4), 1169-1208.

3. Carcello, J. V., \& Neal, T. L. (2003). Audit committee characteristics and auditor dismissals following "new" goingconcern reports. The Accounting Review, 78(1), 95-117.

4. Carey, P., \& Simnett, R. (2006). Audit partner tenure and audit quality. The Accounting Review, 81(3), 653-676.

5. Dao, M., Raghunandan, K., \& Rama, D. V. (2011). Shareholder voting on auditor selection, audit fees, and audit quality. The Accounting Review, 87(1), 149-171.

6. Fahmi, I. (2012). Pengantar pasar modal: panduan bagi para akademisi dan praktisi bisnis dalam memahami pasar modal Indonesia: Penerbit Alfabeta.

7. GAO, G. A. O. (1986). CPA Audit Quality Many Governmental Audits Do Not Comply With Professional Standards. United STates.

8. Garcia-Blandon, J., \& Argiles, J. M. (2015). Audit firm tenure and independence: A comprehensive investigation of audit qualifications in Spain. Journal of International Accounting, Auditing and Taxation, 24, 82-93.

9. Ghosh, A., \& Moon, D. (2005). Auditor tenure and perceptions of audit quality. The Accounting Review, 80(2), 585-612.

10. González-Díaz, B., García-Fernández, R., \& López-Díaz, A. (2014). Auditor tenure and audit quality in Spanish stateowned foundations. Revista de Contabilidad, 18(2), 115-126.

11. Guan, Y., Su, L. N., Wu, D., \& Yang, Z. (2016). Do school ties between auditors and client executives influence audit outcomes? Journal of accounting and economics, 61(2-3), 506-525.

12. Guna, W. I., \& Herawaty, A. (2010). Pengaruh mekanisme good corporate governance, independensi auditor, kualitas audit dan faktor lainnya terhadap manajemen laba. Jurnal bisnis dan akuntansi, 12(1), 53-68.

13. Habib, A., \& Hossain, M. (2013). CEO/CFO characteristics and financial reporting quality: A review. Research in Accounting Regulation, 25(1), 88-100.

14. Harahap, D., Majidah, M., \& Triyanto, D. (2017). Pengujian Fraud Diamond Terhadap Kecurangan Laporan Keuangan. eProceedings of Management, 4(1). 
15. He, X., Pittman, J. A., Rui, O. M., \& Wu, D. (2017). Do social ties between external auditors and audit committee members affect audit quality? The Accounting Review, 92(5), 61-87.

16. Hoitash, R., Markelevich, A., \& Barragato, C. A. (2007). Auditor fees and audit quality. Managerial Auditing Journal, 22(8), 761-786.

17. Knechel, W. R., \& Vanstraelen, A. (2007). The relationship between auditor tenure and audit quality implied by going concern opinions. AUDITING: A journal of practice \& theory, 26(1), 113-131.

18. Kwak, B. J., \& Yu, J. Y. (2015). The Effect of CEO/CFO Ties to Auditors through Outside Directorship on Auditor Selection and Subsequent Audit Quality. 한국회계학회 학술발표논문집, 2015(1), 1113-1160.

19. Kwon, S. Y., \& Yi, H. (2017). Do Social Ties between CEOs and Engagement Audit Partners Affect Audit Quality and Audit Fees? Auditing: A Journal of Practice and Theory.

20. Levitt, A., \& Securities, U. (2000). Speech by SEC chairman: Remarks before the conference on the rise and effectiveness of new corporate governance standards. Federal Reserve Bank, New York,[Online] Available: http://www. sec. gov/news/speech/spch449. htm on, 19(10), 2009.

21. Qi, B., Yang, R., \& Tian, G. (2017). Do social ties between individual auditors and client CEOs/CFOs matter to audit quality? Asia-Pacific Journal of Accounting \& Economics, 24(3-4), 440-463.

22. Rinanda, N., \& Nurbaiti, A. (2018). Pengaruh Audit Tenure, Fee Audit, Ukuran Kantor Akuntan Publik Dan Spesialisasi Auditor Terhadap Kualitas Audit (studi Pada Perusahaan Manufaktur Subsektor Aneka Industri Yang Terdaftar Di Bursa Efek Indonesia Tahun Periode 2012-2016). eProceedings of Management, 5(2).

23. Singgih, E. M., \& Bawono, I. R. (2010). Pengaruh Independensi, Pengalaman, Due Professional Care dan Akuntabilitas Terhadap Kualitas Audit. Simposium Nasional Akuntansi XIII, 1-21.

24. Suwito, E., \& Herawaty, A. (2012). Analisis pengaruh karakteristik perusahaan terhadap tindakan perataan laba yang dilakukan oleh perusahaan yang terdaftar di Bursa Efek Jakarta.

25. wiryanto. (2000). Teori Komunikasi Masa. In: Gramedia Widiasarana Indonesia,Jakarta.

26. Yuniarti, R. (2011). Audit firm size, audit fee and audit quality. 